\title{
Variation in the colour of the keel petals in Lotus corniculatus L. 5. Successional differences in the distribution of dark-keeled plants
}

\author{
S. G. Compton*, \\ S. G. Beesley† and \\ David A. Jones $\nmid \ddagger$
}

\author{
* Department of Zoology and Entomology, \\ Rhodes University, Grahamstown 6140, South Africa. \\ $\dagger$ Department of Plant Biology and Genetics, \\ University of Hull, Hull HU6 7RX.
}

Using individual plants of Lotus corniculatus as the focus of $1 \mathrm{~m}^{2}$ sampling units the plant species associated with L. corniculatus of known phenotype for the colour of their keel petals have been recorded in the chalk quarry at Wharram, North Yorkshire. Multivariate analyses revealed that there was a negative association between the frequency of dark-keeled plants and the percentage of bare ground within each sampling unit and almost no association with any particular plant species. Thus dark-keeled plants were commoner than the light-keeled form in the denser, more mature grassland vegetation. An increase in the frequency of dark-keeled plants in the more mature vegetation was observed between 1980 and 1984. This was not associated with any selective damage by herbivores to petals, buds, pods or leaves nor were there any differences between the morphs for infestation by seed herbivores. While there was more damage to pods in the areas with less mature vegetation there was no evidence of any differences between the morphs in the production of good, viable seed.

\section{INTRODUCTION}

In the United Kingdom Lotus corniculatus L. is almost exclusively polymorphic for the genetic polymorphism of dark and light-keel petals, (Jones, 1977; Jones and Crawford, 1977; Abbott, 1981; Crawford and Jones, 1986) dark keels being dominant (Ramnani and Jones, 1984). The darkkeeled plants are commoner in the north east of England and in eastern Scotland than elsewhere and there is a very marked west to east cline between latitudes $53^{\circ} 30^{\prime} \mathrm{N}$ and $54^{\circ} 30^{\prime} \mathrm{N}$ in England (Crawford and Jones, 1986).

We have no evidence that colonization by flower feeding insects is influenced by petal phenotype, nor do pollinating bees appear to discriminate consistently between different keel colours while foraging (Jones et al., 1986). There is some evidence, however, that the bumble-bee Bombus lapidarius L. preferentially forages darkkeeled plants in cloudy conditions and that the dark-keeled plants (in one population at least) produce more viable seed overall (Jones et al., 1986).

$\ddagger$ Reprint requests to D. A. Jones.
While accumulating data on the distribution of the dark-keeled morph we have obtained evidence of local small scale variation. A particularly good example is among plants growing in and around Wharram Quarry (National Grid Reference SE 860653 , latitude $54^{\circ} 04^{\prime} \mathrm{N}, 131 \mathrm{~m}$ above sea level) in the Yorkshire Wolds (fig. 1). Some of the pastures to the west and south of Wharram Quarry are ancient domains associated with the deserted medieval village of Wharram Percy. In these pastures the frequency of the dark-keeled morph of L. corniculatus ranges from $53 \cdot 9$ to 82.6 per cent (Samples 1, 3, 4, 5, 7 and 11 in table 1), whereas in the quarry random samples from different parts of the quarry and on different occasions had frequencies ranging from 36.9 to 51.0 per cent (including samples 8,9 and 10 in table 1). Two areas near the quarry have frequencies of 50.0 and 51.0 per cent (samples 2 and 6 in table 1), but these were known to have been disturbed during the past 50 years. The land to the north and west of the quarry is arable and for at least the past decade it has grown cereals.

There is prime facie evidence, therefore, that the dark-keeled morph is less common in the more disturbed areas in and around Wharram Quarry, 


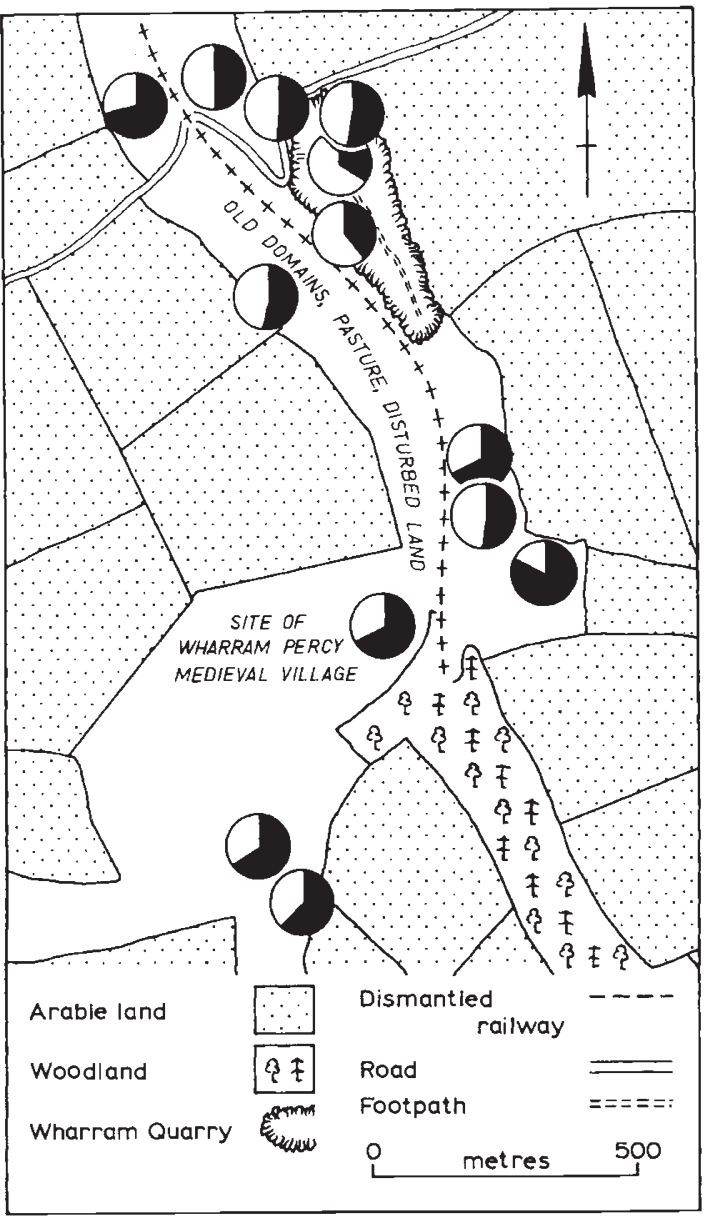

Figure 1 Wharram Quarry, North Yorkshire and environs. The pies show the locations of groups of Lotus corniculatus sampled outside the quarry, the size of the black section indicating the proportion of dark-keeled plants in the sample. The data and map references are in Table 1

and we can ask whether there is an increase in the frequency of the dark-keeled form as the grassland matures. Clearly the selective pressures acting on plants during the establishment phase are likely to be different from those which operate during the later stages of succession. In this paper we examine whether these differences are reflected in the frequency of dark-keeled individuals in vegetation at different stages of a successional sequence.

\section{LOCALITY, MATERIALS AND METHODS}

The plants used during this work were exactly the same individuals as those tested for petal and leaf cyanogenesis (Compton et al., 1986). Thus the detailed description of the habitat in Wharram
Quarry will not be repeated here. It is necessary to explain, however, that the flat, dry quarry floor is a mosaic of bare chalk, chalk rubble and cinders supporting a rich calcicolous flora. It has been deliberate management policy to scrape off the top soil layer from different parts of the quarry from time to time so that different stages in the successional sequence are always available for teaching and research purposes.

Sampling took place in the section of the quarry floor to the north and west of the main entrance, extending over an area of $100 \times 125 \mathrm{~m}$. Metal pipes were inserted into the chalk at $25 \mathrm{~m}$ intervals to form a grid from which random coordinates could be determined. The $L$. corniculatus individual nearest to each coordinate, together with the vegetation in the surrounding $\mathrm{m}^{2}$ formed the basic sampling unit of which 207 (one incomplete) were collected on fourteen dates between April and September 1980. This type of sampling conforms to that recommended by Heltshe and Ritchey (1984) for detecting clumping, although we were allowing for patterns in the vegetation types rather than of patterns in the distribution of individual plants of particular species.

The following procedure was carried out with each sample:

1. From each plant three flower umbels were removed for phenotype determinations. If conflicting phenotype scores were obtained the sample was assumed to have been based on two or more individuals and was discarded.

2. Any remaining flowers and seed pods were collected for scoring of damage. Usually each flower and pod was examined individually, but with some very large plants it was necessary to extrapolate from sub-samples.

3. The area of ground covered by the plant was determined by recording the length of twenty equally spaced radii extending from its centre. A modified dart-board "spider" was used for this purpose. Surface area was calculated from the mean length of the radii.

4. Five leafy stems were removed from different parts of the plant to provide an estimate of leaf damage. The terminal bud and first four leaves (20 leaflets) were examined, with damage to each leaflet being scored as nil (0), nominal (1), less than 25 per cent removed (2), greater than 25 per cent removed (3), or totally removed (4). The values in parentheses were used to produce an overall damage score for each plant. Extensively chewed leaflets were given a weighting equal to that of totally removed leaflets because large amounts of chewing were considered to 
Table 1 The frequency of the dark-keeled form of Lotus corniculatus in and around Wharram Quarry, North Yorkshire. All the sites are in the $10 \mathrm{~km}$ square 86 of the $100 \mathrm{~km}$ square $\mathrm{SE}(44)$

\begin{tabular}{|c|c|c|c|c|}
\hline Site & Date & $\begin{array}{l}\text { Map } \\
\text { reference }\end{array}$ & $\begin{array}{l}\text { No. of } \\
\text { plants in } \\
\text { sample }\end{array}$ & $\begin{array}{l}\text { Percentage } \\
\text { with dark } \\
\text { keels }\end{array}$ \\
\hline 1 & 13.6 .1978 & 856654 & 52 & $71 \cdot 2$ \\
\hline 2 & 27.6.1978 & 857654 & 50 & $50 \cdot 0$ \\
\hline 2 & 14.8 .1987 & & 67 & $50 \cdot 7$ \\
\hline \multicolumn{5}{|c|}{ repeated } \\
\hline 3 & 2.7 .1978 & 858641 & 116 & $66 \cdot 4$ \\
\hline 4 & 15.7 .1979 & 858651 & 39 & 53.9 \\
\hline 5 & 2.7 .1978 & 859640 & 50 & $64 \cdot 0$ \\
\hline 6 & 27.6 .1978 & 859654 & 101 & $50 \cdot 5$ \\
\hline 7 & 12.6 .1978 & 859652 & 65 & $40 \cdot 0$ \\
\hline 7 & 27.6 .1978 & & 139 & $41 \cdot 7$ \\
\hline \multicolumn{5}{|c|}{ repeated } \\
\hline $8^{*}$ & 13.6 .1978 & 859653 & 147 & $51 \cdot 0$ \\
\hline $9 \dagger$ & 12.6 .1978 & 859653 & 139 & $35 \cdot 3$ \\
\hline 9 & 27.6.1978 & & 252 & 36.9 \\
\hline \multicolumn{5}{|c|}{ repeated } \\
\hline 10 & 15.6 .1979 & 860645 & 60 & $66 \cdot 7$ \\
\hline 11 & 14.8 .1987 & 862648 & 31 & $67 \cdot 7$ \\
\hline 12 & 14.8 .1987 & 862647 & 96 & $51 \cdot 0$ \\
\hline 13 & 13.6.1978 & 863646 & 46 & $82 \cdot 6$ \\
\hline
\end{tabular}

* Large plants

$\dagger$ Random sample of plants of all sizes

be particularly indicative of those plants which were highly palatable to herbivores.

5. Cover estimates were produced for the plant species growing in the surrounding $\mathrm{m}^{2}$, together with an estimate of the extent of any bare ground. Grass species were not recorded individually, but were combined as "total Gramineae". Other reasons for treating the grasses in this way are given in Compton et al. (1986).

The same area was also sampled systematically by removing a single flower umbel from plants growing at least one metre apart. The characteristics of this sampling method have been discussed elsewhere (Jones, 1977). Supplementary information on the distribution of the keel-colour phenotypes was obtained from large collections in the same section of the quarry on 5 June 1984 and 29 June 1984.

Phenotype determinations were carried out shortly after collection. The colour of the keel tips was scored as light or dark, depending on the presence or absence of any red-brown pigmentation. "Pale" keels (Jones and Crawford, 1977) were included in the dark keel category. Leaves and petals were tested for cyanogenesis using the standard tests (e.g., Jones, 1977; Tantisewie et al., 1969).
The names of plants follow Clapham, Tutin and Warburg (1981).

\section{RESULTS}

The proportions of dark-keeled and cyanogenic individuals that formed the basis of the sampling units are given in table 2(i). As the plants were monomorphic for petal cyanogenesis this character will not be considered further. Not all plants were in flower at the time of sampling and this is reflected in the number of plants that were scored for keel petal colour. The combination of phenotypes for keel colour and leaf cyanogenesis are given in table 2(ii). There is no indication of any relationship between the expression of keel colour and cyanogenesis.

An ordination of the vegetation in the $1 \mathrm{~m}^{2}$ quadrats was carried out using the correspondence analysis (reciprocal averaging) programme in the GENSTAT Macro library (Alvey et al., 1982). This technique provides a means of plotting both plant species and individual quadrats in the same coordinate system. The uses of correspondence analysis have been reviewed by Gauch (1982) who concluded that for most analyses of community data sets this method has advantages over principal components analysis. Bare ground 'cover' and total Gramineae were included as variables in the ordination, but not the rarer plant species, nor Ononis repens, which proved to be an extreme outlier when

Table 2 Phenotype frequencies in the randomly selected $L$. corniculatus plants at Wharram Quarry 1980

(i) Phenotype frequencies

\begin{tabular}{llll}
\hline & \multicolumn{2}{c}{ Phenotypes } & \\
\cline { 2 - 3 } & cyanogenic & acyanogenic & Totals \\
\hline 1. Leaf cyanogenesis & 165 & 41 & 206 \\
2. Petal cyanogenesis & 136 & 0 & 136 \\
3. Keel colour & Dark & Light & \\
& 52 & 83 & 135 \\
\hline
\end{tabular}

(ii) Combinations of phenotypes

\begin{tabular}{|c|c|c|c|c|}
\hline & & \multicolumn{3}{|l|}{ Leaf } \\
\hline & & $\begin{array}{l}\text { cyano- } \\
\text { genic }\end{array}$ & $\begin{array}{l}\text { acyano- } \\
\text { genic }\end{array}$ & Totals \\
\hline Keel & Dark & 44 & 8 & 52 \\
\hline \multirow[t]{2}{*}{ Colour } & Light & 67 & 16 & 83 \\
\hline & & 111 & 24 & 135 \\
\hline
\end{tabular}

$\chi_{[1]}^{2}=0.33, P>0.05$. 
included in preliminary analyses. Eigen values for the first three axes were $0.3812,0 \cdot 1746$ and $0 \cdot 1174$ respectively. Figs 2-3 illustrate the distribution of the plant species and the sample quadrats in the first two ordination axes. The quadrats and plant species are displayed separately in order to improve the clarity of the presentation. The amount of bare ground present appears to be the most indicative of the variables contributing to the separation of the quadrats in the first axis (fig. 4), with Thymus praecox (and correlated species) equally indicative in the second (see Compton et al., 1986).

Comparison of the distribution of dark and light-keel centred quadrats along the first two ordination axes suggests that their relative proportions vary in different sections of the orientation space (fig. 3). Although light-keel centred quadrats are less frequent at the lowest values on the first axis, in the section where bare ground was rare or absent (fig. 4), this is not statistically significant (table 3 ).

The vegetation in the $1 \mathrm{~m}^{2}$ quadrats was separated into discrete groupings using a cluster analysis programme (CLUSTAN, Wishart, 1975-Ward's method) on the same data set. Two primary groups were distinguished (designated A and B, with 142 and 65 quadrats respectively) and one major subdivision (A1 and A2, with 20 and 122 quadrats). Most of the quadrats that comprise vegetation group B are concentrated in the section of the ordination space where bare ground was rare or absent. The proportions of dark-keeled petals in the three vegetation groups were 15.4 per cent (A1), 39.8 per cent (A2) and 43.6 per cent (B). Analysis based on the original numbers again shows no significant variation between groups $\left(\chi_{[2]}^{2}=3 \cdot 41, P>0 \cdot 05\right)$ although dark-keeled plants are commoner in the type $B$ vegetation.

Fig. 5 illustrates the distribution of the vegetation groups on the floor of Wharram Quarry. Vegetation of type B was recorded mainly in three distinct "islands" (one of which is bisected by a path) and around the periphery of the quarry. These three areas (separated by diagrammatic boundary lines in fig. 5) are clearly recognisable in the field, being composed of a tall grass sward which is often abruptly demarcated from the surrounding more open sections which comprise vegetation group A. Most examples of type A1 vegetation were widely scattered (fig. 5) and the subdivisions of the type $A$ vegetation are not readily distinguishable in the field. Stepwise discriminant function analysis (Mahal method) was used to determine the best combinations of factors for distinguishing the vegetation groups defined by the cluster analysis (cf. Mathews, 1979). Grass

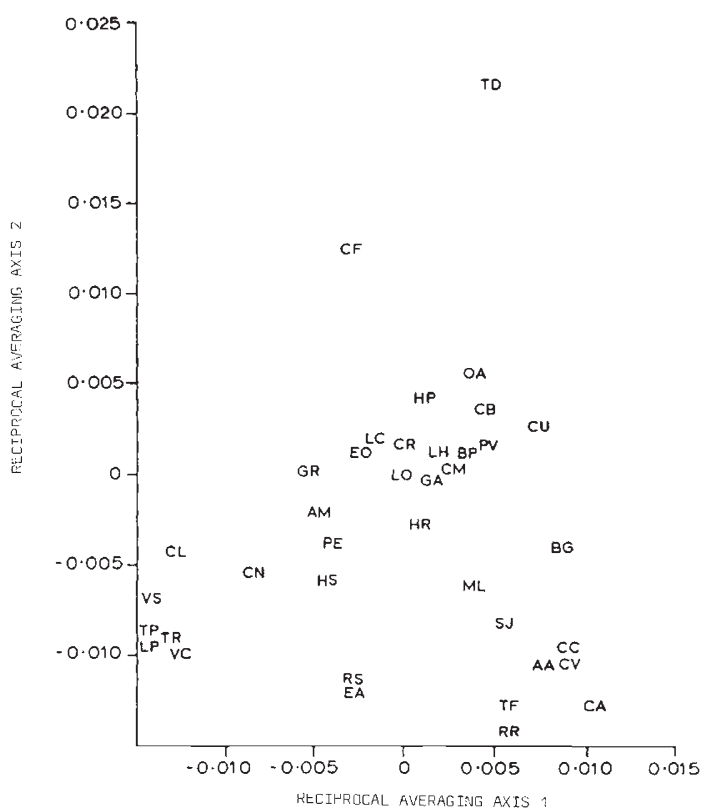

Figure 2 Ordination of plant species in $1 \mathrm{~m}^{2}$ quadrats surrounding $L$. corniculatus plants at Wharram Quarry on RA axes 1 and 2 .

$\begin{array}{ll}\text { Abbreviations } \\ \text { AA } & \text { Anagallis arvensis } \\ \text { AM } & \text { Achillea millefolium } \\ \text { BG } & \text { Bare ground } \\ \text { BP } & \text { Bellis perennis } \\ \text { CA } & \text { Cirsium arvense } \\ \text { CB } & \text { Cerastium arvense } \\ \text { CC } & \text { Crepis capillaris } \\ \text { CF } & \text { Carex flacca } \\ \text { CL } & \text { Galium cruciata } \\ \text { CM } & \text { Crataegus monogyna } \\ \text { CN } & \text { Centaurea nigra } \\ \text { CR } & \text { Campanula rotundifolia } \\ \text { CU } & \text { Carlina vulgaris } \\ \text { CV } & \text { Cirsium vulgaris } \\ \text { EA } & \text { Chamerion angustifolium } \\ \text { EO } & \text { Euphrasia officinalis } \\ \text { GA } & \text { Gentianella amarella } \\ \text { GR } & \text { Total Gramineae } \\ \text { HP } & \text { Hieracium pilosella } \\ \text { HR } & \text { Hypochaeris radicata } \\ \text { HS } & \text { Heracleum sphondylium } \\ \text { LC } & \text { Linum catharticum } \\ \text { LH } & \text { Leontodon hispidus } \\ \text { LO } & \text { Lotus corniculatus } \\ \text { LP } & \text { Lathyrus pratensis } \\ \text { ML } & \text { Medicago lupulina } \\ \text { OA } & \text { Ophrys apifera } \\ \text { PE } & \text { Picris echioides } \\ \text { PV } & \text { Prunella vulgaris } \\ \text { RS } & \text { Rosa sp. } \\ \text { RR } & \text { Ranunculus repens } \\ \text { SJ } & \text { Senecio jacobaea } \\ \text { TD } & \text { Thymus praecox } \\ \text { TF } & \text { Tussilago farfara } \\ \text { TP } & \text { Trifolium pratense } \\ \text { TR } & \text { Trifolium repens } \\ \text { VC } & \text { Veronica chamaedrys } \\ \text { VS } & \text { Vicia sepium } \\ & \end{array}$




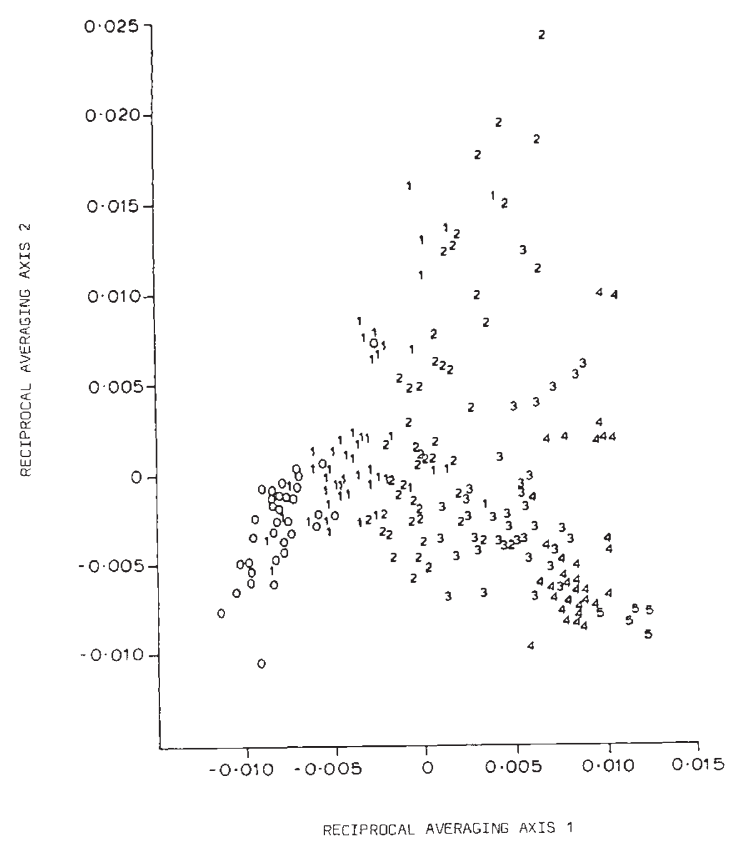

Figure 3 Ordination of $1 \mathrm{~m}^{2}$ sample quadrats surrounding dark-keeled (D), light-keeled (L) and non-flowering plants (.) at Wharram Quarry.

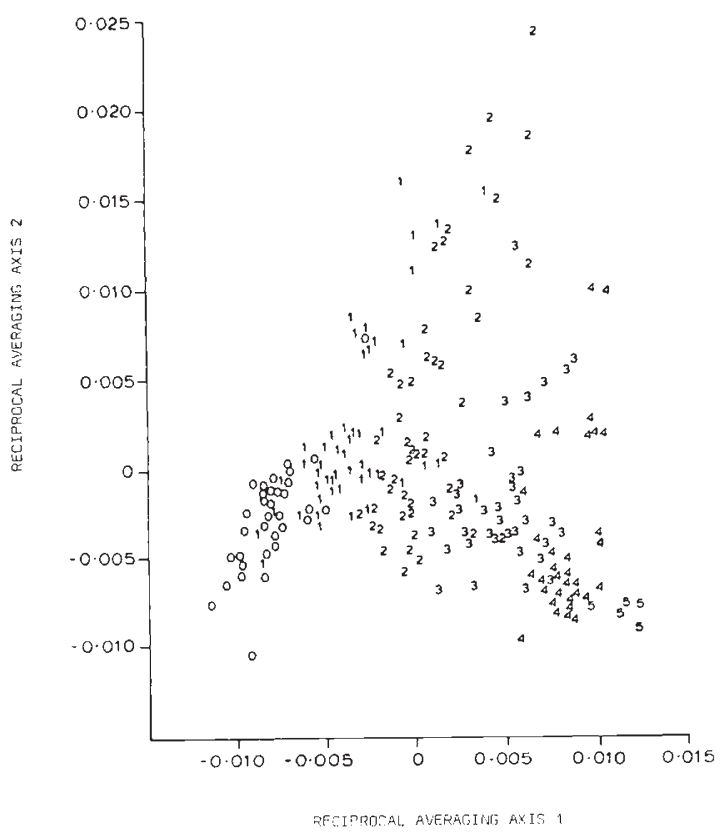

Figure 4 Ordination of $1 \mathrm{~m}^{2}$ sample quadrats displaying the area of bare ground in each quadrat. $0=<1$ per cent bare ground, $1=1-10$ per cent, $2=11-25$ per cent, $3=26-50$ per cent, $4=51-75$ per cent and $5=>75$ per cent.
Table 3 The distribution of dark and light keeled individuals among randomly selected $L$. Corniculatus at Wharram Quarry in relation to the area of bare ground in the surrounding $1 \mathrm{~m}^{2}$ (1980 data)

\begin{tabular}{lll}
\hline & \multicolumn{2}{c}{ Number of plants in $1 \mathrm{~m}^{2}$ quadrats } \\
\cline { 2 - 3 } & $\begin{array}{l}10 \text { per cent or } \\
\text { less bare ground }\end{array}$ & $\begin{array}{l}\text { Greater than } 10 \\
\text { per cent bare ground }\end{array}$ \\
\hline Phenotype & 15 & 37 \\
Light & 17 & 66
\end{tabular}

$\chi_{[1]}^{2}=1 \cdot 24, P>0 \cdot 05$.

cover was found to be the major factor separating group A and B, with Crepis capillaris and Ranunculus repens important in distinguishing $\mathrm{A} 1$ and A2. (Appendix 1).

Keel-colour frequencies were re-scored in 1984. The sampling was based on the two major vegetation types and because of the difficulty of distinguishing the A1 and A2 types reliably in the field this subdivision was not made. Phenotype frequencies were found to vary between the two major vegetation types, with plants that had dark-keeled flowers occurring more frequently in the grassy type B areas (table 4(i)). An increased proportion of dark-keeled plants was evident in all three "islands" of type B vegetation, which did not differ significantly in their keel colour frequencies (table 4(ii)). The 206 plants sampled in 1980 also showed a high proportion of dark-keeled plants in type B vegetation, but it was only when the two large samples collected independently in 1984 were combined that the 5 per cent level of significance was reached in the $\chi^{2}$ analysis. Notice, also, that plants of both phenotypes flower later in the type $\mathrm{B}$ vegetation $\left(\chi_{[1]}^{2}=168 \cdot 1, P \ll 0.001\right)$. Of particular interest is the significant change in frequency of the dark keeled form in type B vegetation overall from 43.6 per cent in 1980 to 56.0 per cent in 1984 (table 4(iii)). The three sub-samples of type B vegetation taken in 1984 show that all three are homogeneous in this change in frequency (table 4(ii)).

Table 5 summarises comparisons of the size and reproductive output of the $L$. corniculatus individuals in relation to their background vegetation and phenotypes. The plants growing in the more open (type A) plant assemblages were generally smaller than those in the closed sward (type B) and, in relation to their size, produced more flowers (table 5(i)). Despite the differences in their surroundings the density of the plants (measured as dry weight/ground area covered) was not different in the two areas (Mann-Whitney $\mathrm{U}=$ 


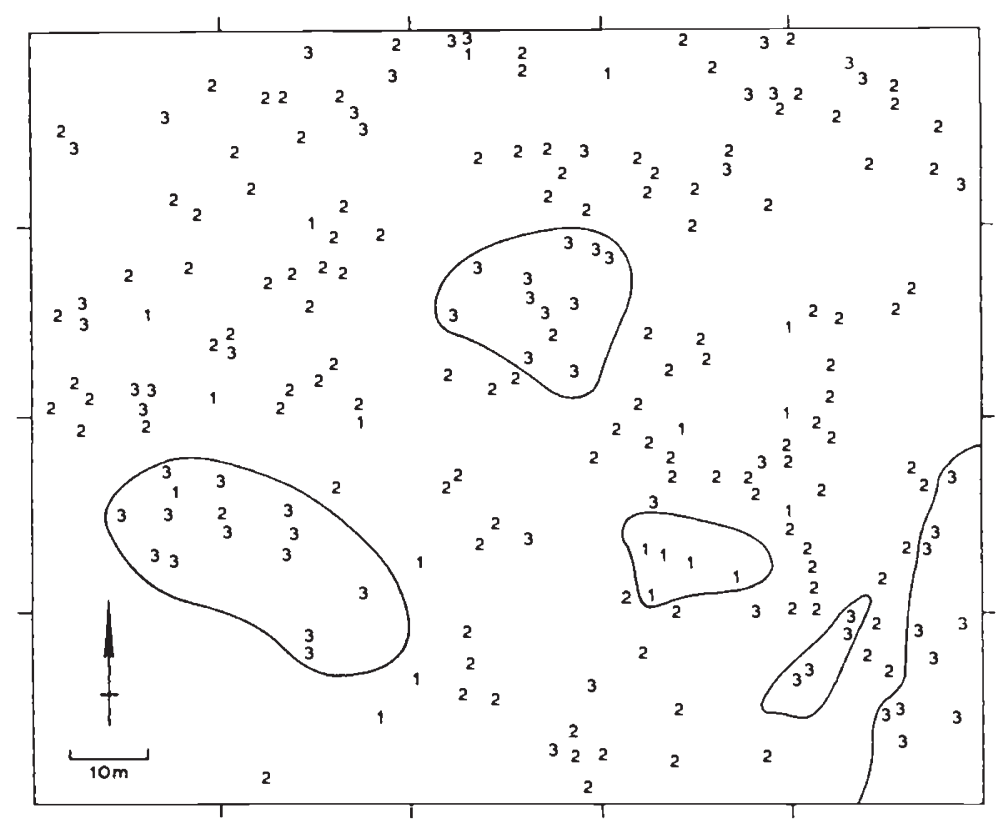

Figure 5 The distribution of the three vegetation types in the study area at Wharram Quarry. (Vegetation type A1 =1, A2 = 2, B = 3).

$4274 \cdot 9, n 1=141, n 2=65, P>0.05)$. Flower production by plants growing in the extremely open type A1 areas was not greater than that recorded from the rest of the type A assemblage (table 5(ii)). No differences in the size of plants of different phenotype are evident, but light-keeled plants had marginally more flowers than dark-keeled ones (table 5(iii)).

Comparisons of leaf, terminal bud, flower and seed pod damage scores are given in tables 6-8. Leaf damage scores based on leaf chewing did not differ between assemblages A and B, nor between plants with different keel colour phenotypes (table 6 ). Terminal bud damage did not vary significantly between phenotypes or assemblages (table 7). Damage to the seed pods was infrequent, particularly in the type $B$ vegetation areas and no between-phenotype differences in seed pod damage were detected (Table 8).

\section{DISCUSSION}

Lotus corniculatus has been used as a model species for several ecological studies. Usher (1975) chose the plant from among those studied by Burden (1970) in Wharram Quarry because "it appeared to be one of the first colonizers of bare chalk, and nitrogen fixation in its root nodules, and hence a local nitrogen availability, may act as a stimulus for other plant species to become established". Reader and Southwood (1981) surprisingly did not regard the plant as an example of an early successional species, rather including it in their mid successional assemblage.

Davis et al. (1985) studied the effect on the development of the vegetation of introducing $L$. corniculatus (and Brachypodium sylvaticum) into a sparsely vegetated area ( $<10$ per cent) of a limestone quarry. The species was chosen, again, because it is one of the most widespread, early and persistent herb colonists of chalk and limestone quarries throughout England (Davis, 1983) and because of the long term beneficial effects of the legumes on soil nitrogen. In none of these studies has the known genetical variation in $L$. corniculatus been taken into account, even when it was directly relevant. Reader and Southwood (1981), for example, ignored the polymorphism for cyanogenesis when they were assessing the palatability of the plant to herbivores when it was already known that one of the animals they used, Agriolimax (Deroceras) reticulatus, was a selective herbivore of acyanogenic $L$. corniculatus (Jones, $1962 a, b, 1966)$. Furthermore, it was not part of any of these studies to observe any interactions between the variation in $L$. corniculatus and other vegetation in the habitat.

Starting with studies in the Netherlands (Ellis, Keymer and Jones, 1976) we have developed a 
Table 4 The frequency of keel colour phenotypes of $L$. corniculatus in vegetation zones on the floor of Wharram Quarry, June 1984

(i) Vegetation groups $\mathrm{A}$ and $\mathrm{B}$

\begin{tabular}{|c|c|c|c|c|c|c|}
\hline \multirow[b]{2}{*}{ Sampling dates } & \multicolumn{2}{|c|}{ Group A } & \multicolumn{2}{|c|}{ Group B } & \multirow[b]{2}{*}{$\chi_{[1]}^{2}$} & \multirow[b]{2}{*}{$P$} \\
\hline & Light & Dark & Light & Dark & & \\
\hline 5.6 .84 & 119 & 112 & 28 & 44 & $3 \cdot 50$ & $>0.05$ \\
\hline 29.6 .84 & 74 & 64 & 154 & 188 & $2 \cdot 91$ & $>0.05$ \\
\hline Totals & 193 & 176 & 182 & 232 & 5.44 & $<0.05$ \\
\hline
\end{tabular}

Heterogeneity $\chi_{[1]}^{2}=0.97, P>0.05$.

(ii) "Islands" of group B vegetation

\begin{tabular}{|c|c|c|c|c|c|c|c|c|}
\hline \multirow[b]{2}{*}{ Sampling dates } & \multicolumn{2}{|c|}{ "Island" B1 } & \multicolumn{2}{|c|}{ “Island" B2 } & \multicolumn{2}{|c|}{ "Island" B3 } & \multirow[b]{2}{*}{$\chi_{[2]}^{2}$} & \multirow[b]{2}{*}{$P$} \\
\hline & Light & Dark & Light & Dark & Light & Dark & & \\
\hline 5.6 .84 & 10 & 14 & 8 & 5 & 10 & 25 & 4.45 & $>0.05$ \\
\hline 29.6 .84 & 46 & 54 & 53 & 61 & 55 & 73 & $0 \cdot 36$ & $>0.05$ \\
\hline Totals & 56 & 68 & 61 & 66 & 65 & 98 & $2 \cdot 03$ & $>0.05$ \\
\hline
\end{tabular}

Heterogeneity $\chi_{[1]}^{2}=2 \cdot 78, P>0 \cdot 05$.

(iii) The numbers of plants of each phenotype in type B vegetation in 1980 and 1984

\begin{tabular}{lcccl}
\hline Sampling dates & Light & Dark & $\chi_{[1]}^{2}$ & $P$ \\
\hline 1980 & 32 & 23 & 3.96 & $>0.05$ \\
1984 & 182 & 232 & & \\
\hline
\end{tabular}

novel and unique approach to predictive ecology based on the known variation within a plant species, the most successful study being on Holy Island, Angelsey (Ellis, Keymer and Jones, 1977; Compton, Beesley and Jones, 1983). Here we have shown, beyond reasonable doubt, that selective grazing by molluses is the predominant agent determining the distribution of cyanogenic $L$. corniculatus on the west coast of Holy Island. At Wharram Quarry we have used individual $L$. corniculatus plants as the focus of sampling the surrounding vegetation both for plant and animal species. It was only after the data were collected for each quadrat sampled that the focal plant was tested for leaf and petal cyanogenesis (Compton, Beesley and Jones, 1986). That study showed a clear association between a more mature stage in the succession in the quarry and the occurrence of leaf cyanogenic plants although it was not possible to determine, at that time, why this should be. The most likely explanation is that under certain conditions leaf cyanogenic $L$. corniculatus has a faster rate of root growth than the acyanogenic form (Keymer and Ellis, 1978). This might provide an important advantage when root competition is intense, and so allow cyanogenic plants to persist for longer periods under these conditions.
At the same time that these $L$. corniculatus plants at Wharram Quarry were tested for cyanogenesis they were also scored for the colour of the keel petals and this means that exactly the same data set was available for two analyses, one based on cyanogenic/acyanogenic plants and the other on dark/light-keeled plants.

The A1, A2 and B vegetation assemblages at Wharram represent stages in a successional sequence which broadly correspond to groups $\mathrm{A}$, B and C in Usher's (1979) description of succession at the quarry. They can be described as pioneer, chalk grassland and meadow communities. Arrhenatherum elatius, a tall grass which is common at Wharram, was noticeably rare in the quadrats centred on $L$. corniculatus, suggesting that the presence of this species may be indicative of the stage in the succession when $L$. corniculatus is eliminated.

The data collected in 1984 show a significant excess of dark-keeled plants in the more mature parts of Wharram Quarry (table 4(i)). This distribution of the keel colour phenotypes shows an interesting parallel with that for leaf cyanogenesis in the quarry (Compton et al., 1986), cyanogenic plants also occurring more frequently in the areas of dense grassland. The expression of the keel 
Table 5 Mann-Whitney U test analysis of the reproductive effort, size and surroundings of $L$. corniculatus at Wharram Quarry (1980)

(i) Comparisons between vegetation groups $\mathrm{A}$ and $\mathrm{B}$

\begin{tabular}{|c|c|c|c|c|c|c|}
\hline & \multicolumn{2}{|c|}{ Group A } & \multicolumn{2}{|c|}{ Group B } & \multirow[b]{2}{*}{$U$} & \multirow[b]{2}{*}{$P$} \\
\hline & $n$ & Mean rank & $n$ & Mean rank & & \\
\hline Bare Ground in $\mathrm{m}^{2}$ & 142 & $129 \cdot 88$ & 65 & $47 \cdot 45$ & $939 \cdot 5$ & $<0.001$ \\
\hline Grass cover in $\mathrm{m}^{2}$ & 142 & $80 \cdot 04$ & 65 & $156 \cdot 35$ & $1212 \cdot 5$ & $<0.001$ \\
\hline Area of central $L$. corniculatus & 142 & $92 \cdot 32$ & 65 & $129 \cdot 52$ & $2956 \cdot 5$ & $<0.001$ \\
\hline Flowers present & 142 & $109 \cdot 37$ & 65 & $92 \cdot 27$ & $3852 \cdot 5$ & $>0.05$ \\
\hline Flowers/unit area & 142 & $112 \cdot 71$ & 65 & $84 \cdot 96$ & $3377 \cdot 5$ & $<0.01$ \\
\hline Flowers/unit mass* & 118 & $85 \cdot 62$ & 42 & $66 \cdot 12$ & $1874 \cdot 0$ & $<0.05$ \\
\hline
\end{tabular}

(ii) Comparisons between vegetation groups $\mathrm{A} 1$ and $\mathrm{A} 2$

\begin{tabular}{|c|c|c|c|c|c|c|}
\hline & \multicolumn{2}{|c|}{ Group Al } & \multicolumn{2}{|c|}{ Group A2 } & \multirow[b]{2}{*}{$U$} & \multirow[b]{2}{*}{$P$} \\
\hline & $n$ & Mean rank & $n$ & Mean rank & & \\
\hline Bare Ground in $\mathrm{m}^{2}$ & 20 & $102 \cdot 47$ & 122 & $66 \cdot 42$ & $600 \cdot 5$ & $<0.001$ \\
\hline Grass cover in $\mathrm{m}^{2}$ & 20 & $56 \cdot 15$ & 122 & $74 \cdot 02$ & $913 \cdot 0$ & $>0.05$ \\
\hline Area of central $L$. corniculatus & 20 & $72 \cdot 87$ & 122 & $71 \cdot 27$ & $1192 \cdot 5$ & $>0.05$ \\
\hline Flowers present & 20 & $65 \cdot 17$ & 122 & $72 \cdot 54$ & $1093 \cdot 5$ & $>0.05$ \\
\hline Flowers/unit area & 20 & $65 \cdot 08$ & 122 & $72 \cdot 55$ & $1091 \cdot 5$ & $>0.05$ \\
\hline Flowers/unit mass* & 13 & $52 \cdot 38$ & 90 & 51.94 & $580 \cdot 0$ & $>0.05$ \\
\hline
\end{tabular}

(iii) Comparisons between keel colour phenotypes

\begin{tabular}{|c|c|c|c|c|c|c|}
\hline & \multicolumn{2}{|c|}{ Light } & \multicolumn{2}{|c|}{ Dark } & \multirow[b]{2}{*}{$U$} & \multirow[b]{2}{*}{$P$} \\
\hline & $n$ & Mean rank & $n$ & Mean rank & & \\
\hline Bare Ground in $\mathrm{m}^{2}$ & 82 & $70 \cdot 37$ & 52 & $64 \cdot 22$ & $1961 \cdot 5$ & $>0.05$ \\
\hline Grass cover in $\mathrm{m}^{2}$ & 83 & $63 \cdot 16$ & 52 & $75 \cdot 72$ & $1756 \cdot 5$ & $>0.05$ \\
\hline Area of central $L$. corniculatus & 83 & $71 \cdot 42$ & 52 & $62 \cdot 55$ & $1874 \cdot 5$ & $>0.05$ \\
\hline Flowers/unit area & 83 & $72 \cdot 09$ & 52 & $61 \cdot 47$ & $1818 \cdot 5$ & $>0.05$ \\
\hline Flowers/unit mass* & 62 & $51 \cdot 87$ & 40 & $50 \cdot 92$ & $1217 \cdot 0$ & $>0.05$ \\
\hline
\end{tabular}

* Includes only plants with a diameter of less than $25 \mathrm{~cm}$.

colour and cyanogenic phenotypes does not appear to result from genetic linkage, suggesting that separate factors are acting to influence their distribution. In the case of keel colour we have no direct information about which factors may be involved, but at Wharram Quarry L. corniculatus plants growing in the grassy areas commence

Table 6 Analysis of variance of the leaflet damage sustained by $L$. corniculatus at Wharram Quarry. Angular transformed damage scores are based on samples of 100 leaflets ( 5 stems, 4 nodes 5 leaflets per node) from each plant. Maximum damage score attainable was 400 (1980 data)

\begin{tabular}{lrll}
\hline Keel colour phenotypes & \multicolumn{1}{l}{$\mathrm{df}$} & $\mathrm{ms}$ & $P$ \\
\hline Between groups & 1 & $15 \cdot 285$ & $>0.05$ \\
Within groups & 133 & $31 \cdot 270$ & \\
$\quad$ Total & 134 & & \\
\hline
\end{tabular}

Mean damage scores: light keel, 87.99, dark keel, 90.76. flowering somewhat later than those growing in the more open areas.

It was noticeable that the plants growing among the more mature vegetation were larger than those in the more open sward, but they produced fewer flowers per unit area. Although it was possible to distinguish subdivisions of the more open sward during the analysis, it was not easy to pick these out on the ground. Bare ground was the major discriminating feature, but it was difficult to make subjective judgements in the field in 1984 and so the distinction was not made. The problem was made more difficult by the fact that the vegetation was four years more mature and there was less bare ground than previously. The distinction between the A type and B type vegetation was clear, however, and there was no doubt that darkkeeled plants were commoner in the type B than in the type $A$ vegetation. 
Table 7 The levels of terminal bud damage sustained by $L$. corniculatus at Wharram Quarry. Five terminal buds were examined on each plant (1980 data)

Keel colour phenotypes

\begin{tabular}{lrrrrrrrrl}
\hline \multicolumn{7}{c}{$\begin{array}{l}\text { No. of damaged buds } \\
\text { recorded per plant }\end{array}$} & & & \\
\cline { 2 - 7 } Phenotype & 0 & 1 & 2 & 3 & 4 & 5 & $\chi_{[5]}^{2}$ & $P$ \\
\hline Light & 18 & 16 & 30 & 13 & 3 & 3 & & \\
Dark & 7 & 12 & 16 & 12 & 4 & 1 & 3.95 & $>0.05$ \\
\hline
\end{tabular}

Mean damaged buds per sample: light keel, 1.71, dark keel, 1.94 .

As the vegetation in the quarry has been allowed to develop naturally it is most likely that the $L$. corniculatus plants in the quarry were derived, ultimately, from plants that grew in the surrounding pasture. In these old pastures the frequency of dark-keeled plants is consistently higher than in the pioneer vegetation in the quarry. If we assume that the higher frequencies in the old pastures are near to equilibrium, which is not unreasonable as the area is at the high frequency end of the cline across northern England (Crawford and Jones, 1988), we have to conclude that light keeled plants have an advantage in the pioneer population in the quarry.

There is independent evidence from two sources that the frequency of the dark-keeled form increases as the vegetation matures. Table 4(i) shows that the frequency of the dark-keeled form is significantly higher in the type B vegetation than in the type A while a significant increase in the frequency of the dark-keeled form in type B vegetation over the four years $1980-84$ is shown in table 4(iii).

As yet we have no direct evidence to explain why this has occurred. Jones et al. (1986) found no significant differences in the production of healthy seed between a premarked sample of lightand dark-keeled plants at Wharram Quarry in 1982. Furthermore there was no difference between the morphs in infestation by seed herbivores. In July 1986, however, there was a significant excess of Thysanoptera adults in dark as opposed to light

Table 8 The levels of petal and seed pod damage sustained by $L$. corniculatus at Wharram Quarry in 1980

(i) Flower petal damage

(a) Wharram vegetation groupings

\begin{tabular}{llcccc}
\hline Group & Damaged flowers & Undamaged flowers & $\chi_{[1]}^{2}$ & $P$ & \multicolumn{1}{c}{$\begin{array}{l}\text { Per cent } \\
\text { damaged }\end{array}$} \\
\hline A & 314 & 1458 & & & 17.72 \\
B & 97 & 472 & 0.13 & $>0.05$ & 17.05 \\
\hline
\end{tabular}

(b) Keel colour phenotypes

\begin{tabular}{lllccc}
\hline Phenotype & Damaged flowers & Undamaged flowers & $\chi_{[1]}^{2}$ & $P$ & $\begin{array}{l}\text { Per cent } \\
\text { damaged }\end{array}$ \\
\hline Light & 268 & 1366 & & & 16.40 \\
Dark & 115 & 82 & 2.52 & $>0.05$ & $19 \cdot 27$ \\
\hline
\end{tabular}

(ii) Seed pod damage

(a) Wharram vegetation groupings

\begin{tabular}{lccccc}
\hline Group & Damaged pods & Undamaged pods & $\chi_{[1]}^{2}$ & $P$ & $\begin{array}{c}\text { Per cent } \\
\text { damaged }\end{array}$ \\
\hline A & 44 & 846 & & & 4.94 \\
B & 4 & 332 & $9 \cdot 13$ & $<0 \cdot 01$ & $1 \cdot 19$ \\
\hline
\end{tabular}

(b) Keel colour phenotypes

\begin{tabular}{lccccc}
\hline Phenotype & Damaged pods & Undamaged pods & $\chi_{[1]}^{2}$ & $P$ & $\begin{array}{l}\text { Per cent } \\
\% \text { damaged }\end{array}$ \\
\cline { 1 - 3 } Light & 33 & 633 & & & 4.95 \\
Dark & 8 & 211 & 0.63 & $>0.05$ & 3.65 \\
\hline
\end{tabular}


keeled flowers, but as this was the only significant $\chi^{2}$ value in 13 similar tests the effect may well be the result of chance. Tables 6,7 and 8 in this paper show an absence of any selective leaf, bud, petal and pod damage by herbivores although a higher proportion of the pods in type A vegetation were damaged than in type B. Because all the plants tested had cyanogenic petals the data in tables 7 and $8(\mathrm{i})$ are not complicated by cyanogenesis. The plants were polymorphic for cyanogenesis in their leaves and thus there was confounding with petal colour in table 6. As it happens there is no significant difference between the two petal-colour types and so cyanogenesis is not a complication in this particular set of data.

We have observed a change in the frequency of the dark-keeled form in the type B vegetation between 1980 and 1984 and the situation is being studied further. The management policy in Wharram Quarry is to clear to bare chalk parts of the quarry floor on a regular and planned basis and this means that there are regions of known stages in a successional sequence. In the long-term, therefore, it should be possible to monitor the changes in the frequency of the dark-keeled form in the quarry both over time and space and to study the effects of severe droughting as occurred, for example, in 1975 and 1976.

Acknowledgments We are grateful to Valerie Fairhurst for her technical assistance and to the SERC for financial support. We are also grateful to the Yorkshire Wildlife Trust (the managers) and to the Lord Middleton and Birdsall Estates (the owners) for permission to work in Wharram Quarry. The constructive criticism of a referee was greatly appreciated.

\section{REFERENCES}

AвBOTT, R. J. 1981. The keel petal colour polymorphism of Lotus corniculatus L. in Scotland. New Phytologist, 88, $549-553$.

Alvey, N., Galwey, N. AND LANE, P. 1982. An Introduction to GENSTAT. Academic Press.

BURDEN, P. C. 1970. Field and computer studies in the pattern of some calcicolous plants. B.A. Thesis, University of York.

CLAPHAM, A. R., TUTIN, T. G. AND WARBURG, E. F. 1981. Excursion Flora of the British Isles, Third Edition. Cambridge University Press.

COMPTON, S. G., BEESLEY, S. G. AND JONES, D.A . 1983. On the polymorphism of cyanogenesis in Lotus corniculatus L. 9. Selective herbivory in natural populations at Porthdafarch, Anglesey. Heredity, 51, 537-547.

COMPTON, S. G., BEESLEY, S. G. AND JONES, D. A. 1986. On the polymorphism of cyanogenesis in Lotus corniculatus L. 10. Successional differences in the distribution of cyanogenic and acyanogenic plants. Journal of Natural History, 20, 1443-1460.

CRAWFORD, T. J. AND JONES, D. A. 1986. Variation in the colour of the keel petals in Lotus corniculatus L. 2. Clines in Yorkshire and adjacent counties. Watsonia, 16, 15-19.
CRAWFORD, T. J. AND JONES, D. A. 1988. Variation in the colour of the keel petals in Lotus corniculatus L. 4. Morph distribution in the British Isles. Heredity, 61, 175-188.

DAVIS, B. N. K. 1983. Plant succession in chalk and ragstone quarries in south east England. Proceedings of the Croydon Natural History and Scientific Society, 17, 154-172.

DAVIS, B. N. K., LAKHANI, K. H., BROWN, M. C. AND PARK, D. G. 1985. Early seral communities in a limestone quarry: an experimental study of treatment effects on cover and richness of vegetation. Journal of Applied Ecology, 22, 473490.

ELLIS, W. M., KEYMER, R. J. AND JONES, D. A. 1976. On the polymorphism of cyanogenesis in Lotus corniculatus L. 6. Ecological studies in the Netherlands. Heredity, 36, 245251.

ELlis, W. M., KEYMER, R. J. AND JONES, D. A. 1977. On the polymorphism of cyanogenesis in Lotus corniculatus L. 8. Ecological studies in Anglesey. Heredity, 39, 45-65.

GAuCH, H. G. 1982. Multivariate Analysis in Community Ecology. Cambridge University Press.

HELTSHE, J. F. AND RITCHEY, T. A. 1984. Spatial pattern detection using quadrat samples. Biometrics, 40, 877-885.

JONES, D. A. $1962 a$. Selective eating of the acyanogenic form of the plant Lotus corniculatus L. by various animals. Nature, 193, 1109-1110.

JONES, D. A. 1962 b. Studies on the Polymorphism and Antibody Formation in Lower Organisms and their bearing on Ecological Genetics and Human Serology. D. Phil. Thesis, University of Oxford.

JONES, D. A. 1966. On the polymorphism of cyanogenesis in Lotus corniculatus. Selection by animals. Canadian Journal of Genetics and Cytology, 8, 556-567.

JONES, D. A. 1977. On the polymorphism of cyanogenesis in Lotus corniculatus L. VII. The distribution of the cyanogenic form in Western Europe. Heredity, 39, 27-44.

JONES, D. A. AND CRAWFORD, T. J. 1977. Variation in the colour of the keel petals in Lotus corniculatus L. 1. The polymorphism in Western Europe. Heredity, 39, 313-325.

JONES, D. A., COMPTON, S. G., CRAWFORD, T. J., ELLIS, W. M. AND TAYLOR, I. M. 1986. Variation in the colour of the keel petals in Lotus corniculatus L. 3. Pollination, herbivory and seed production. Heredity, 57, 101-112.

KEYMER, R. J. AND ELLIS, W. M. 1978. Experimental studies on plants of Lotus corniculatus L. from Anglesey polymorphic for cyanogenesis. Heredity, 40, 189-206.

MATHEWS, J. A. 1979. A study of the variability of some successional and climax plant assemblage types using multiple discriminant analysis. Journal of Ecology, 67, 255-271.

RAMNANI, A. D. AND JONES, D. A. 1984. Inheritance of the brown keel tip character in Lotus corniculatus L. Bangladesh Journal of Botany, 13, 52-59.

READER, P. M. AND SOUTHWOOD, T. R. E. 1981. The relationship between palatability to invertebrates and the successional status of the plant. Oecologia, 51, 271-275.

TANTISEWIE, B., RUIJGROK, H. W. L. AND HEGNAUER, R. 1969. Die verbreitung der blausäure bei den Cormophyten. 5. Mitteilung: Über cyanogene verbindungen bei den parietales und bei einingen weiteren sippen. Pharmaceutisch Weekblad, 104, 1341-1355.

USHER, M. B. 1975. Analysis of pattern in real and artificial plant populations. Journal of Ecology, 63, 569-586.

USHER, M. B. 1979. Natural communities of plants and animals in disused quarries. Journal of Environmental Management, $8,223-236$.

WISHART, D. 1975. CLUSTAN IC User's Manual. London University Press. 


\section{APPENDIX 1}

Discriminant function analysis separating the vegetation groupings obtained by cluster analysis of cover values in $1 \mathrm{~m}^{2}$ quadrats at Wharram Quarry

1. Vegetation groups A and B

\begin{tabular}{lll}
\hline & & $\begin{array}{l}\text { Standardised } \\
\text { discriminant } \\
\text { function coefficient }\end{array}$ \\
\hline 1 & Total Gramineae & -0.476 \\
2 & Centaurea nigra & -0.236 \\
3 & Hieracium pilosella & $0 \cdot 287$ \\
4 & Leontodon hispidus & 0.414 \\
5 & Thymus praecox & 0.281 \\
6 & Bare Ground' & 0.227 \\
7 & Rosa sp. & -0.263 \\
8 & Picris echiodes & -0.250 \\
9 & Veronica chamaedrys & -0.159 \\
10 & Euphrasia officinalis & -0.208 \\
11 & Hypochaeris radicata & 0.146 \\
12 & Achillea millefolium & -0.168 \\
13 & Heracleum sphondylium & -0.184 \\
14 & Vicia sepium & -0.165 \\
15 & Prunella vulgaris & 0.152 \\
16 & Ophrys apifera & 0.162 \\
17 & Senecio jacobaea & 0.124 \\
18 & Ranunculus repens & 0.143 \\
19 & Bellis perennis & 0.142 \\
20 & Cerastium arvense & 0.118 \\
21 & Tussilago farfara & 0.103 \\
\hline & &
\end{tabular}

Discriminant function group mean for assemblage $\mathrm{A}=0.955$. Discriminant function group mean for assemblage $\mathrm{B}=-2 \cdot 09$. 93.2 per cent of the quadrats were "correctly" classified by the function.
2. Vegetation groups $\mathrm{A} 1$ and $\mathrm{A} 2$

\begin{tabular}{lll}
\hline Step & Variable entered & $\begin{array}{l}\text { Standardised } \\
\text { discriminant } \\
\text { function coefficient }\end{array}$ \\
\hline 1 & Crepis capillaris & 1.018 \\
2 & Ranunculus repens & $1 \cdot 193$ \\
3 & Cirsium arvense & 0.923 \\
4 & Anagallis arvensis & 0.727 \\
5 & Senecio jacobaea & 0.656 \\
6 & Tussilago farfara & 0.462 \\
7 & Chamerion angustifolium & 0.393 \\
8 & Rosa sp. & -0.284 \\
9 & 'Bare Ground' & -0.246 \\
10 & Leontondon hispidus & -0.173 \\
11 & Linum catharticum & -0.151 \\
12 & Campanula rotundifolia & -0.110
\end{tabular}

Discriminant function group mean for assemblage $\mathrm{A} 1=6 \cdot 341$. Discriminant function group mean for assemblage A2 $=1 \cdot 040$. 100 per cent of the quadrats were "correctly" classified by the function. 